\title{
CURRENT SINO-RUSSIAN RELATIONS AND THEIR IMPACT ON MONGOLIA
}

\section{L.Hashbat}

Sino-Russian relations, due to geography and geopolitics, are one of the key factors that influence Mongolia's international position and internal development. These bilateral relations influence, directly and indirectly, virtually all issues of international life just as the latter influence Sino-Russian relations which are Mongolia's immediate international environment.

I have given myself the rather narrow task of attempting to assess factors that influence the state and direction of Sino-Russian relations at present, and to draw some conclusions for practical purposes.

Before doing so, I will try to give an assessment of the state of both countries from the standpoint of their internal political development since theoretically this is the starting point for explaining international power parameters of every country.

The disintegration of the Soviet Union, the inability to quickly bring about a new socio-political system, and the sharpening of all economic, political and social conflicts have spawned four simultaneous crises in Russia, constitutional, economic, political, and federal. Moreover, these crises have a severe impact not only on Russia's strategic security but also on its relations with other states both along its borders and throughout the world.

Compared to Russia, the situation in China is stable and the economy is booming. For the last fourteen years China's GNP has grown annually at nine per cent, bringing China into the ranks of the world's most prosperous economies. Although communism and socialism have lost their attractiveness, China under the slogan of "building socialism'with Chinese characteristics" continues to keep tight control over Chinese society where a "guided introduction of differences" is exercised. Guided by the long-standing tradition of Confucian statehood by the yearning of its people for a stable prosperity as well as the negative example of neighboring Russia, the Chinese leadership has apparently found a most rational pattern of concerning China's development and of harmonizing its relations with the outside world. This stability may be interrupted by changes in the leadership and their domestic and international impact. To all appearances, the country's leadership is working out responses to several events likely to occur in the near future. 
The collapse of the Soviet Union and the emergence of a conglomeration of formally independent successor states is the most serious geopolitical factor determining Russo-Chinese relations at present. This factor has undermined not only the system of international relations but stability' on the vast EuroAsian continent as well, and has put Russia and China in a qualitatively different relationship.

Russia's grave weakening in the political, economic and ideological arenas has also weakened its position in Asia as a whole and toward China in particular. Only its status as a world nuclear power still allows Russia to maintain its full standing within the Asia-Pacific region, and specifically within the strategic quadrangle of Russia, the United States, China and Japan.

Fundamental changes in the world order and a shift in Russia's status have given rise to a reappraisal of values and foreign policy directions in both Russia and China. In Russia the search for new directions is still continuing. The leadership is still in the process of elaborating new foreign policies and of building a consensus for them within the country.

As for China, a search for new foreign policy directions has not yet started. Nevertheless, the reformers' consolidation of power within the Communist party and the strengthening of Jiang Zemin's position may mean that in the immediate future China's foreign policy will continue along modernist and centrist lines, expanding China's influence firmly but cautiously while at the same lime emphasizing economic growth and political stability at home.

It will be most difficult for Russia to reconcile itself to a permanent loss of its world power status, whereas China has been cautious and almost fearful about undertaking a larger role in regional and world affairs. So far China has stayed aloof from international cooperation in matters of world and regional security, but under the new conditions it will soon have to try on the role of a major regional if not yet a full-fledged world power on which Asian and global stability depends.

The larger environment in which Sino-Russian relations operate is greatly influenced by the United States and Japan. Following the Soviet Union's disintegration and changes in Russo-American relations, the United States no longer needs China as a geopolitical ally and China, for its part, is not interested in a quasi-alliance with the United States. The latter seeks to maintain as long as possible an equilibrium and stability in the region by allowing neither Russia to further weaken nor China and Japan to continue to gain strength. Russia's weakening has enhanced the importance of American relations with China and 
Japan as guarantees of stable development of the Asia-Pacific region and the role of the United States as the region's balancer.

Japan, until now, has persevered in its policy of linking political and economic matters when dealing with Russia, hoping thereby to regain what it calls the "Northern Territories," better known as the Southern Kuriles. This tough policy has been wholly unsuccessful. The sooner Japan will abandon this policy, the sooner it will have a chance to more effectively influence both Russia and China.

Let us now turn to the relationship between Russia and China Following the Soviet Union's disintegration in 1991 Russian foreign policy under Yeltsin and Kozyrev sought ways to strengthen the reformers' domestic position at the expense of international support. An orientation toward the Euro-American version of democracy and market economy determined an "Atlantic" tendency in Russian foreign policy. It was shaped partly by Yeltsin's internal political considerations.

Another force shaping Russian foreign policy at that time was a desire to eradicate an image abroad of Russia being a backward Asian country and to present it as a European nation with a tradition of enlightenment and a certain political culture. Both forces placed Asia, including China, on the backburner.

This new orientation was instantly criticized by those who saw Russia's future solely as a Euro-Asian power. They criticized the "Atlantic" faction for underestimating the importance of the Pacific for the country's future, the rise of militant Islam in Central Asia, and the growing influence of China. Now, two years after the "Atlantic" victory, one can detect a shift in Russian foreign policy toward a Euro-Asian orientation, as indicated by Yeltsin's visits to South Korea, India, and China, greater attention being paid to Japan, and Russian statements about its own priorities in Euro-Asia. The strengthening of a EuroAsian orientation is explained, in my view, by the deepening social chaos in the country, the West's slowness in rendering substantial aid to Russia, the tough struggle for influence in Central Asia with fundamentalist Muslim countries and their political institutions, the growth of centrifugal trends in Siberia and the Maritime Province, and by the attractiveness of an East Asian model for economic growth under conditions of political guidance. One should also note Russian economic considerations. Apart from up-to-date Western technology Russia needs commodity markets for its military equipment and industrial products as well as markets for its military equipment and industrial products as well as markets for imported consumer goods. In addition, a perceived complementarity of Russia and the rapidly developing countries of East Asia, as well as the 
urgent need to develop the resources of Siberia and the Maritime Province have turned Russia's policy toward the East, including China of these several factors accounting for a shift toward the East and closer cooperation with China, three are of special importance.

1. Attractiveness of the East Asian model of economic development.

After initially flirting with the Euro-American form of democracy, Russia's

leaders began to realize not only that this form was not very appropriate for their country but that the linkage, always insisted on by the West, between this form of democracy and successful economic development was spurious. As a result, Russia's leaders have begun to shift to the East Asian model which already has had a most salutary effect on Russo-Chinese relations. Both countries are building their relations solely on the basis of practical interests and purposes. Ideology and politically insignificant border issues no longer impinge upon Russo-Chinese relations. Instead, both countries are attracted to each other by other factors of which I will single out the two most important ones.

2. Multi-ethnic states struggling against disintegration.

Centrifugal trends in the Russian Federation has now reached the level of Russian-populated regions and probably poses the greatest danger to Russia's territorial integrity. A clear danger signal was given on February 5-6, 1993, when leaders of eight geographical "associations" covering all of Russia, met in Volgograd to discuss ways to achieve greater autonomy. This new force of regionalism is felt in both the political and economic arena. Beyond Russia, its influence in Central Asia is also being undermined. If most Russians should decide to leave that region, a Greater Turkestan movement might once again emerge which would be a nightmare for China. It is precisely growing regionalism and the Muslim factor that make China one of only few countries positively interested in keeping Russia intact as a single centralized state, especially since Russian economic reconstruction is estimated to take at least twenty to thirty years.

\section{Mutual economic interests.}

For the purpose of modernizing its armed forces, China recently purchased 26 SU-27 military aircraft and is about to obtain the same number of those planes again. It is also interested in acquiring long-range interceptors, its own aircraft carriers and modern submarines. According to Yeltsin, Russia has sold China 
armaments and military equipment worth US 18 billion. For its part, China manufactures weaponry according to Russian specifications and sells it to countries such as Syria, Iran, North Korea, and others. Russia needs hard currency and employment at the factories of its military-industrial complex while China needs equipment to make its armed forces capable of fighting far away from Chinese borders. In addition, both Russia and China are interested in the joint development of Siberia, the Maritime Province and Northeast China.

How long will the current stability in Sino-Russian relations last? History shows a pattern of alternating cooperation and rivalry between the two countries. The current period of cooperation and stability will give way to geopolitical forces in both Russia and China. China will renew its drive to extend its influence in the Russian Maritime Province and Eastern Siberia, just as soon as its current drive to affirm its supremacy in the South China Sea is successful. But renewed rivalry between Russia and China is not likely to grow into the kind of harsh antagonism that marked their relationship in the 1960s and 1970s. It would be ideal if both countries allowed themselves to become more interdependent with the rest of the world and thereby accept all principles of international relations. It is my considered opinion, however, that China would be less likely to follow this path. China's leaders are aware of the fact that their country is by far the world's most populous country with the longest, uninterrupted state and state philosophy. Most importantly, China's leaders know very well their country's historical record of culturally absorbing neighbors and conquerors alike.

What is Mongolia's role in Sino-Russian relations? At present its role is rather minimal. Under previous conditions of Sino-Soviet confrontation, Mongolia could to a certain extent influence the balance of power between its two neighbors, but always at the expense of restricting its sovereignty. In the 1950s and early 1960s, during the period of Sino-Soviet cooperation, each nation had attempted to win Mongolia over to its side. It was then that a policy of carefully deriving benefit from "friendly rivalry" would have brought success to Mongolia. Unfortunately, Mongolia's geopolitical situation did not allow such a policy at that time.

It is Mongolia's great fortune today that both of its neighbors are temporarily preoccupied with their own internal problems. This presents Mongolia with a golden opportunity to abandon its role of pawn or hostage of SinoRussian relations and to move into a truly international environment. We must make economic investment in Mongolia attractive to the largest number of states other than our two neighbors. The only feasible way to accomplish this, how- 
ever, is with rapid and energetic measures. Empty slogans and cowardly halfmeasures justified by shortsighted arguments about jeopardizing Mongolia's independence are a sure way to make Mongolia miss this opportunity. If that should happen, our two neighbors will renew their geopolitical interest in Mongolia.

I believe that these remarks are timely because of the current political campaign in Mongolia, the results of which will set the pace of internationalizing our country and will determine its partners. 